\title{
KIMBERLITES OF CENTRAL SASKATCHEWAN (CANADA): COMPILATION AND SIGNIFICANCE OF INDICATOR MINERAL GEOCHEMISTRY WITH RESPECT TO DIAMOND POTENTIAL
}

\author{
S.E. Harvey ${ }^{1}$, B.A. Kjarsgaard ${ }^{2}$ and L.I. Kelley ${ }^{1}$ \\ ${ }^{1}$ Saskatchewan Industry and Resources, Canada; ${ }^{2}$ Geological Survey of Canada
}

The central

Saskatchewan Fort à la

Corne (FalC) kimberlite

field is located $60-\mathrm{km}$ east

of Prince Albert and

comprises over 70 in situ

bodies forming one of the largest diamondiferous kimberlite provinces in the world (Fig. 1) (Scott-Smith et al., 1994). The bulk of the bodies are located in the Fort à la Corne cluster, a north-northwest trending linear zone $50 \mathrm{~km}$ long and $15 \mathrm{~km}$ wide. Several satellite clusters, including the large Snowden cluster to the northeast, the Foxford and Weirdale kimberlites to the northwest, and the Candle Lake kimberlites to the north are also north-northwest trending.

The kimberlites are dissimilar from most kimberlites worldwide in that they are dominantly comprised of 'crater facies' volcaniclastic rocks (Lehnert-Thiel et al., 1992; Scott-Smith et al., 1994), which consist of pyroclastic lapilli- and olivinedominated rocks, local debris flows and reworked volcaniclastic kimberlite (Kjarsgaard et al., 1995; Leckie et al., 1997; Jellicoe et al., 1998; Kjarsgaard et al., 2001). They are

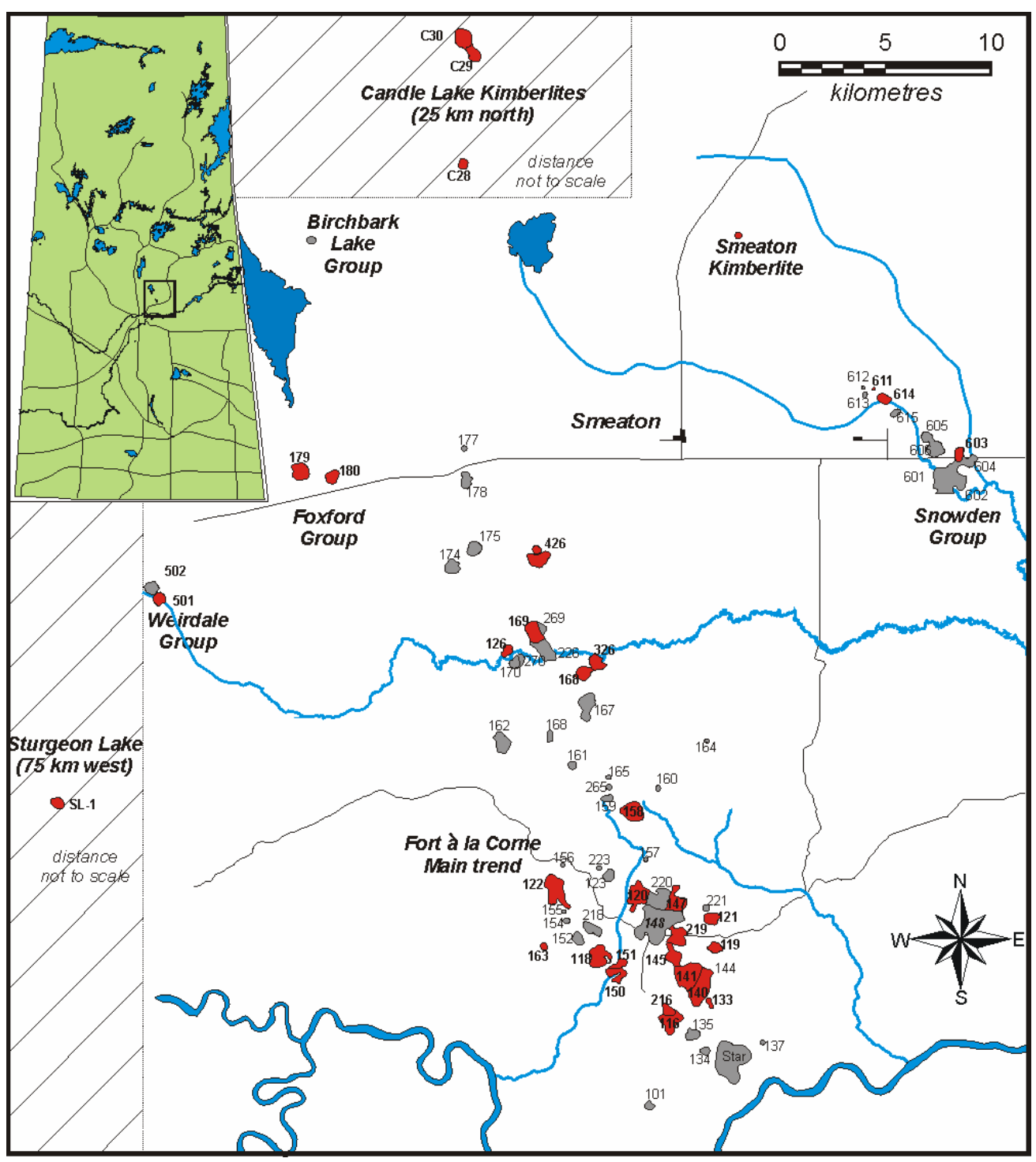

Figure 1: Map of central Saskatchewan kimberlites investigated in this study (red) (modified from Jellicoe et al., 1998). Note: Sturgeon Lake and Candle Lake areas are projected into the location map and distances are not to scale. classified as group I bodies with most containing mantle derived (peridotitic and eclogitic) xenoliths and xenocrysts (e.g. garnet, chromite), along with xenoliths of Archean and Paleoproterozoic basement and Phanerozoic rocks.

Analytical geochemical data for indicator minerals (garnet, chrome spinel and ilmenite) from 33 kimberlites have been compiled from non-confidential government assessment files and interpreted (Table 1). The bulk (22 of 33) of the mineral chemistry data are from kimberlites in the main Fort à la Corne field; the others are from the outlying clusters (Fig 1). The quality of the compiled data is highly variable and caution must be exercised when interpreting it: sampling procedure, mineral selection and analytical methodology varied between companies; sample weights and the number of 
drill holes utilized per kimberlite differed, resulting in a highly variable number of indicator grains analyzed per kimberlite; many of the kimberlite bodies are very large and composite, thus data from one drill hole may not be representative.

\section{Table 1: Summary of heavy mineral sample compositions and counts from the central Saskatchewan kimberlites investigated.}

\begin{tabular}{|c|c|c|c|c|c|c|c|c|c|c|c|c|}
\hline 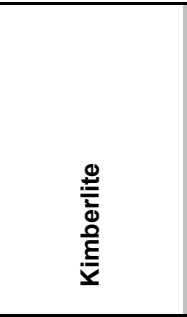 & $\begin{array}{l}\stackrel{+}{ \pm} \\
\frac{5}{5} \\
\frac{0}{0} \\
\frac{\pi}{\pi} \\
\stackrel{0}{0} \\
\mathbf{n}=\end{array}$ & 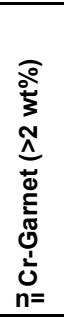 & 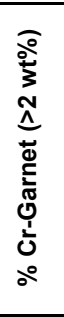 & 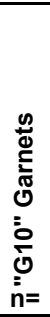 & 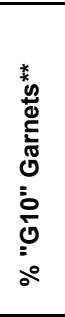 & 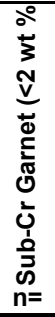 & 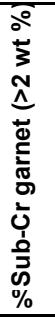 & 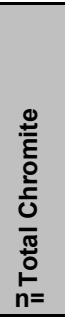 & $\bar{\Delta}$ & $\begin{array}{l}\bar{D} \\
\text { ๙ீ}\end{array}$ & 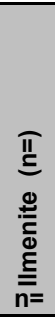 & $\begin{array}{l}\frac{n}{0} \\
\frac{0}{0}\end{array}$ \\
\hline Falc 116 & 34 & 31 & 91 & 2 & 5.9 & 3 & 9 & 105 & 0 & NiI & 23 & poor \\
\hline FalC 118 & 53 & 22 & 42 & 0 & Nil & 31 & 58 & 9 & 0 & Nil & 14 & $v$ good \\
\hline FalC 119 & 400 & 338 & 85 & 0 & Nil & 62 & 16 & 200 & 1 & 0.5 & 187 & good \\
\hline FalC 120 & 392 & 191 & 49 & 12 & 3.1 & 201 & 51 & 46 & 2 & 4.3 & 118 & v good \\
\hline FalC 121 & 46 & 18 & 39 & 3 & 6.5 & 28 & 61 & 13 & 3 & 23.1 & 12 & poor \\
\hline FalC 122 & 500 & 433 & 87 & 11 & 2.2 & 67 & 13 & 270 & 1 & 0.4 & 299 & good \\
\hline FalC 126 & 399 & 355 & 89 & 8 & 2.0 & 44 & 11 & 200 & 15 & 7.5 & 198 & good \\
\hline FalC 133 & 598 & 547 & 91 & 12 & 2.0 & 51 & 9 & 300 & 2 & 0.7 & 300 & good \\
\hline FalC 140 & 700 & 676 & 97 & 40 & 5.7 & 24 & 3 & 395 & 4 & 1.0 & 399 & good \\
\hline FalC 141 & 100 & 89 & 89 & 5 & 5.0 & 11 & 11 & 103 & 3 & 2.9 & 100 & good \\
\hline FalC 145 & 100 & 77 & 77 & 2 & 2.0 & 23 & 23 & 105 & 0 & Nil & 99 & good \\
\hline FalC 147 & 200 & 157 & 79 & 3 & 1.5 & 43 & 22 & 100 & 3 & 3.0 & 100 & good \\
\hline FalC 150 & 247 & 217 & 88 & 4 & 1.6 & 30 & 12 & 215 & 1 & 0.5 & 212 & good \\
\hline FalC 151 & 48 & 17 & 35 & 0 & Nil & 31 & 65 & 9 & 0 & Nil & 13 & good \\
\hline FalC 158 & 42 & 14 & 33 & 1 & 2.4 & 28 & 67 & 14 & 0 & Nil & 15 & good \\
\hline FalC 163 & 203 & 186 & 92 & 8 & 3.9 & 17 & 8 & 187 & 0 & Nil & 126 & good \\
\hline FalC 168 & 99 & 86 & 87 & 0 & Nil & 13 & 13 & 91 & 1 & 1.1 & 103 & good \\
\hline FalC 169 & 294 & 134 & 46 & 25 & 8.5 & 160 & 54 & 78 & 0 & Nil & 97 & good \\
\hline FalC 216 & 99 & 71 & 72 & 1 & 1.0 & 28 & 28 & 66 & 2 & 3.0 & 27 & $\checkmark$ good \\
\hline FalC 219 & 66 & 38 & 58 & 4 & 6.1 & 28 & 42 & 5 & 0 & Nil & 21 & v good \\
\hline FalC 326 & 19 & 13 & 68 & 0 & Nil & 6 & 32 & 115 & 0 & Nil & 97 & poor \\
\hline FalC 426 & 192 & 115 & 60 & 1 & 0.5 & 77 & 40 & 110 & 0 & Nil & 72 & $v$ good \\
\hline Candle Lk 28 & 652 & 588 & 90 & 65 & 10.0 & 64 & 10 & 123 & 6 & 4.9 & 323 & good \\
\hline Candle Lk 29 & 176 & 156 & 89 & 22 & 12.5 & 20 & 11 & 59 & 2 & 3.4 & 10 & gd \\
\hline Candle Lk 30 & 518 & 438 & 85 & 27 & 5.2 & 80 & 15 & 201 & 9 & 4.5 & 55 & good \\
\hline Foxford 179 & 101 & 67 & 66 & 2 & 2.0 & 34 & 34 & 106 & 0 & Nil & 122 & good \\
\hline Foxford 180 & 180 & 159 & 88 & 0 & Nil & 21 & 12 & 30 & 1 & 3.3 & 15 & good \\
\hline Smeaton RS-1 & 29 & 19 & 66 & 0 & Nil & 10 & 34 & 44 & 0 & Nil & ND & \\
\hline Snowden 603 & 47 & 44 & 94 & 0 & Nil & 3 & 6 & 117 & 0 & Nil & 101 & poor \\
\hline Snowden 614 & 28 & 28 & 100 & 0 & Nil & 0 & 0 & 130 & 0 & Nil & 96 & $v$ good \\
\hline Snowden 611 & 63 & 32 & 51 & 2 & 3.2 & 31 & 49 & 17 & 0 & Nil & 20 & $v$ good \\
\hline Sturgeon SL-1 & 89 & 53 & 60 & 0 & $\mathrm{Nil}$ & 36 & 40 & 3 & 0 & Nil & 45 & good \\
\hline Wierdale 501 & 4 & 3 & 75 & 0 & Nil & 1 & 25 & 123 & 0 & Nil & 85 & $\checkmark$ good \\
\hline ** & \multirow{2}{*}{\multicolumn{12}{|c|}{$\begin{array}{l}\% \text { G10 = \# G10/Total Garnets } \\
\text { chromites that plot in the diamond inclusion/intergrowth field } \\
\text { Diamond Preservation Potential: based on comparison with Fipke et al }\end{array}$}} \\
\hline $\begin{array}{l}\text { DI } \\
\text { DPP }\end{array}$ & & & & & & & & & & & & \\
\hline
\end{tabular}

\section{INDICATOR MINERAL CHEMISTRY}

\section{GARNET}

Most of the kimberlite bodies studied are dominated by garnets of peridotitic composition ( $>2 \mathrm{wt}$ $\% \mathrm{Cr}_{2} \mathrm{O}_{3}$ ) (Fig. 2a-c; Table 1). Megacryst garnets, which overlap with P-type, E-type and crustal garnets in the range 0 to 4 wt $\% \mathrm{Cr}_{2} \mathrm{O}_{3}$ and 3.75 to $6.0 \mathrm{wt} \% \mathrm{CaO}$, are common in most bodies (e.g. FalC 140, 169 and Candle 28). $\mathrm{Cr}_{2} \mathrm{O}_{3}$ contents of the P-type garnets reach $15.2 \mathrm{wt} \%$ and $\mathrm{CaO}$ contents vary from 0.6 to $9.7 \mathrm{wt} \%$ with lherzolitic compositions being dominant. This lherzolitic trend is clearly defined in many of the kimberlite bodies (e.g. FalC 140 and Candle Lake 28). Some of the garnets with $>12 \mathrm{wt} \% \mathrm{Cr}_{2} \mathrm{O}_{3}$ may be derived from garnet dunites.

Twenty-two of the 33 kimberlite bodies contained G10 garnets and show a large range in abundance, degree of calcium depletion and chrome enrichment (Fig. 2a-c; Table 1). G10 populations range from 2.6 to $15.2 \mathrm{wt} \% \mathrm{Cr}_{2} \mathrm{O}_{3}$, and 0.9 to $6.2 \mathrm{wt} \% \mathrm{CaO}$. Kimberlites with significant G10 populations include the Candle Lake kimberlites, FalC 169, 140, 141, 120, and 163. A few others possibly contain noteworthy G10 populations, however there are too few data for a meaningful assessment. 
a)

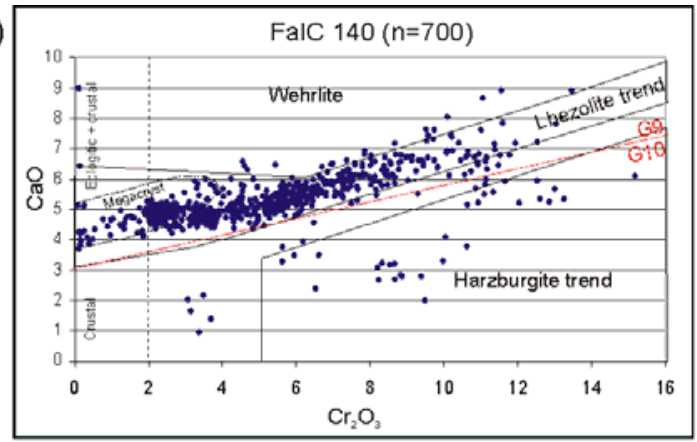

c)

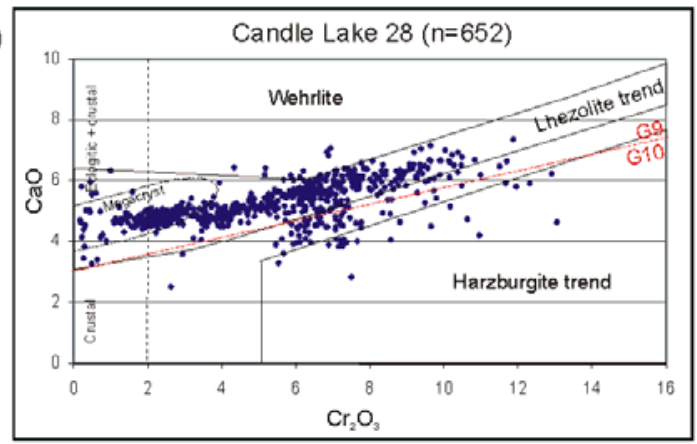

e)

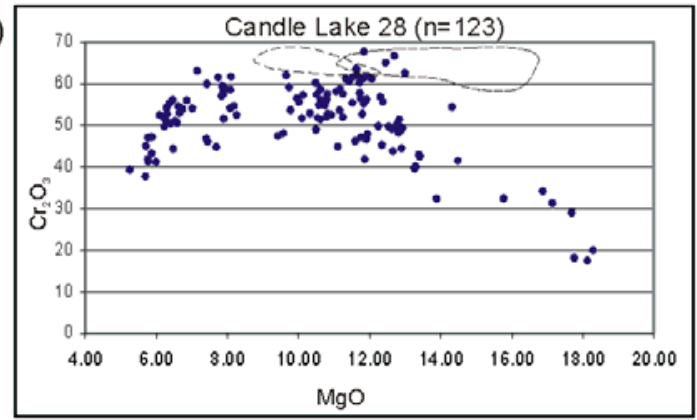

g)

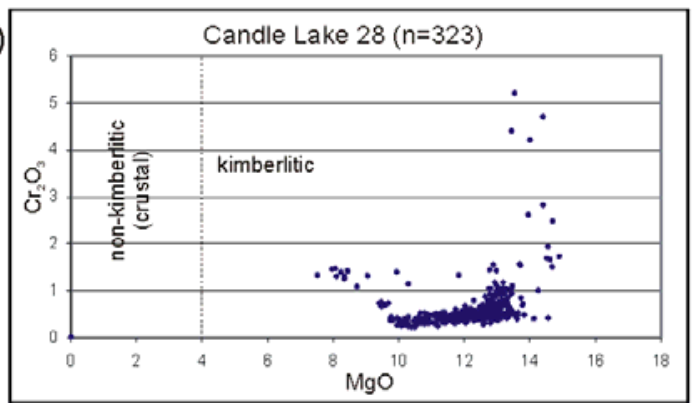

b)

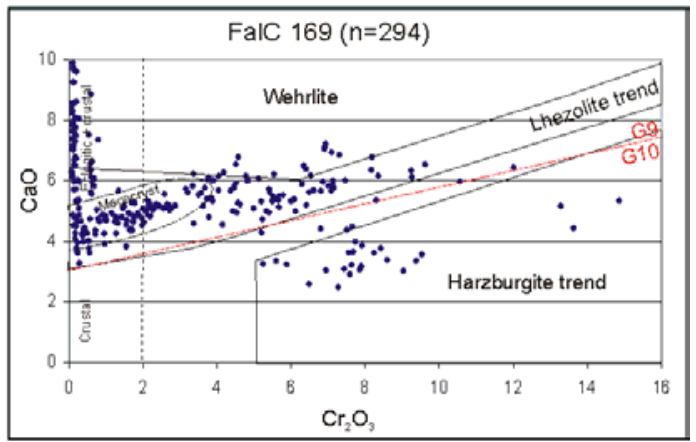

d)

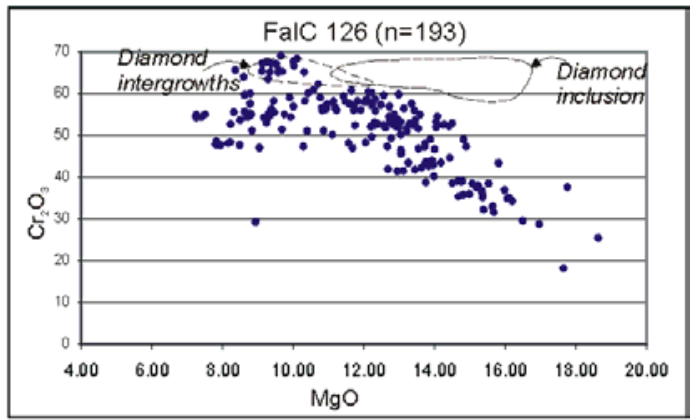

f)

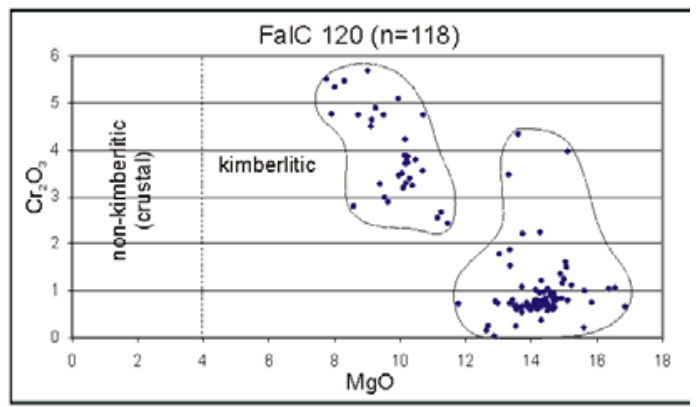

h)

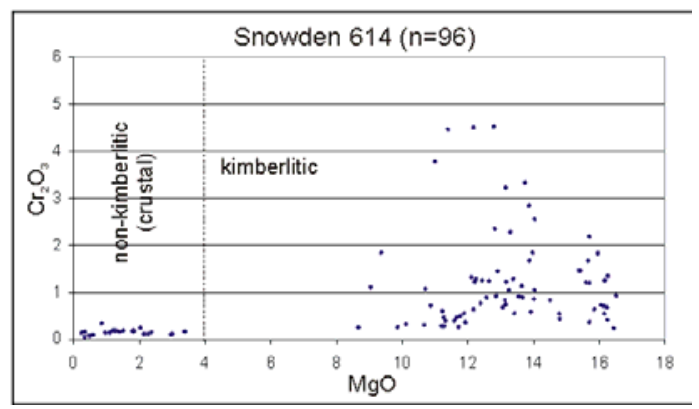

Figure 2: a-c) $\mathrm{CaO}$ versus $\mathrm{Cr}_{2} \mathrm{O}_{3}$ plot of garnets from some of the kimberlites examined in this study (all compositions wt \%) (Peridotite fields from Sobolev et al., 1973; G10/G9 fields from Gurney, 1984; Megacryst field from Schulze, 1993); d-e) $\mathrm{Cr}_{2} \mathrm{O}_{3}$ versus $\mathrm{MgO}_{\mathrm{g}}$ plot of chromite compositions from some of localities investigated (all compositions wt \%) (Diamond intergrowth and inclusion fields after Fipke et al., 1995). f-h) $\mathrm{Cr}_{2} \mathrm{O}_{3}$ versus $\mathrm{MgO}$ plot for ilmenite compositions from some kimberlites investigated (all compositions wt \%).

Gurney (1984) pointed to calcium depletion in the G10 population as another significant indication of prospectivity. Those kimberlites with significant G10 populations, described above, along with substantial calcium depletion $(<3 \mathrm{wt} \% \mathrm{CaO})$ include FalC 120,140 , 141, and 169. FalC bodies 140 and 169 are particularly interesting in that they both have significant G10 populations, with very low calcium and high chromium contents (Fig. 2). Those kimberlites with garnet compositions that spread across and well into the subcalcic G10 field may have the strongest potential for higher diamond contents.

Several of the kimberlites contain a significant population of sub-chromium $\left(<2 \mathrm{wt} \% \mathrm{Cr}_{2} \mathrm{O}_{3}\right)$ eclogite-, 
megacryst- or crust-derived garnet xenocrysts. Figure 2 shows that some of the sub-chromium garnets examined have intermediate-Ca compositions and consequently plot in the megacryst composition field, as seen in FalC 169. In terms of eclogitic differentiation, sodium concentrations in garnets are generally less than $1 \mathrm{wt} \%$, however the accuracy and precision of the $\mathrm{Na}_{2} \mathrm{O}$ analyses are not sufficient to confidently discriminate between group I and group II garnets.

\section{CHROMITE}

Chromite macrocrysts have highly variable compositions, with $\mathrm{MgO}$ values ranging from 1.84 to 19 wt $\%$ and $\mathrm{Cr}_{2} \mathrm{O}_{3}$ values from 16 to $69 \mathrm{wt} \%$. Chromite compositions plotted on a $\mathrm{MgO}-\mathrm{Cr}_{2} \mathrm{O}_{3}$ graph often display an inverted "U" shape (e.g. Candle 28), as previously noted by Jellicoe et al. (1998). Between approximately 5 and 9 wt $\% \mathrm{MgO}$ there is a positive correlation between $\mathrm{Cr}_{2} \mathrm{O}_{3}$ and $\mathrm{MgO}$. Between 9 and 11 wt \% $\mathrm{MgO}, \mathrm{Cr}_{2} \mathrm{O}_{3}$ remains constant, and at $\mathrm{MgO}$ contents greater than about $11 \mathrm{wt} \%$, there is a negative correlation with $\mathrm{Cr}_{2} \mathrm{O}_{3}$ (Fig. 2d-e). Of the studied kimberlites, seven had too few chromite analyses to permit confident interpretation. Of those with larger data sets, 15 contained chromites with compositions similar to chromites from diamond inclusions and intergrowths (i.e. plot in the diamond inclusion and intergrowth (DI) field) (Fig. 2d-e; Table 1). Six of those had less than one percent of their sample set plot in the DI field, while the remaining nine had greater than 2.5 percent of their sampled chromite compositions plot in the diamond inclusion field. The highest proportion of chromites with DI-compositions occurs in FalC 126, 120, Candle Lake 28 and 30, while FalC 141, 147, Candle Lake 29 and Foxford 180 contain appreciable quantities of chromites with DI compositions. FalC 121 also contained 23 percent DI-composition chromites within a very small data set.

\section{ILMENITE}

Ilmenite analyses were available for 32 of the kimberlites, although 6 of those had sample populations of less than 20 (Table 1). Most of the remaining analyses indicate moderate to high $\mathrm{MgO}$ contents (average 12.02 wt $\% \mathrm{MgO}$ ), with highly variable $\mathrm{Cr}_{2} \mathrm{O}_{3}$ contents (Fig. 2fh). Magnesium in some exceeds $16 \mathrm{wt} \% \mathrm{MgO}$, and only one body, Snowden 603, has a relatively low $\mathrm{MgO}$ content (average 9.85 wt \% MgO). Chromium contents are highly variable with some being very low (average < $0.5 \mathrm{wt} \% \mathrm{Cr}_{2} \mathrm{O}_{3}$ ) and others very high (average $>2.5 \mathrm{wt} \%$ $\left.\mathrm{Cr}_{2} \mathrm{O}_{3}\right)$. Crustal ilmenites $(<4 \mathrm{wt} \% \mathrm{MgO})$ are observed in a few bodies, with some having anomalously high concentrations (e.g. Snowden 614).

In terms of diamond preservation, ilmenites with a low $\mathrm{Fe}_{2} \mathrm{O}_{3}\left(\mathrm{Fe}^{+3}\right)$ component are deemed to have formed in a relatively reducing kimberlite, increasing the diamond preservation potential (DPP) (Haggerty, 1986). Ilmenite with relatively high $\mathrm{MgO}$ and low $\mathrm{Fe}_{2} \mathrm{O}_{3}$ is considered to be indicative of reducing conditions in the parent magma. As reducing conditions prevent the oxidation of diamonds, kimberlites containing ilmenite with relatively high $\mathrm{MgO}$ content are considered to have high diamond preservation potential. A very important aspect to note is that the diamond preservation potential is only useful if diamonds were sampled in the first place.

Three compositional groups of ilmenite are distinguished (Fig. 2f-h). The first group defines backwards "L" shaped plots with most grains in the lower part of the graph (e.g. Candle 28). For ilmenites containing 10-15 wt \% $\mathrm{MgO}, \mathrm{Cr}_{2} \mathrm{O}_{3}$ is constant at about $0.75 \mathrm{wt} \%$. In contrast, ilmenites with more than $15 \mathrm{wt} \%$ $\mathrm{MgO}$ exhibit a sharp increase in $\mathrm{Cr}_{2} \mathrm{O}_{3}$ (up to 5 wt \%). This group represents 60 percent of the kimberlite bodies and probably corresponds to the MgO-rich limb of the "Haggerty parabola" (Haggerty, 1975). Most of these bodies have high $\mathrm{MgO}$ and $\mathrm{Cr}_{2} \mathrm{O}_{3}$ contents conducive to diamond preservation. However, four have low $\mathrm{MgO}$ or $\mathrm{Cr}_{2} \mathrm{O}_{3}$ contents that might indicate diamond resorption. FalC 116, 121, and 326 all have very low $\mathrm{Cr}_{2} \mathrm{O}_{3}$ contents $(<0.5$ wt \%), while Snowden 603 has both low $\mathrm{MgO}$ (avg. $9.85 \mathrm{wt} \%$ ) and low $\mathrm{Cr}_{2} \mathrm{O}_{3}$ (avg. $0.49 \mathrm{wt} \%$ ).

FalC 120 (Fig. 2f), 145, 147 and 426 yielded two distinct sub-populations of ilmenite which define the second compositional group. The main sub-population contains high $\mathrm{MgO}$ and low to moderate $\mathrm{Cr}_{2} \mathrm{O}_{3}$ versus the other that is composed of high (2.5 to $6 \mathrm{wt} \%) \mathrm{Cr}_{2} \mathrm{O}_{3}$ and variable $\mathrm{MgO}$ ( 7.5 to $12 \mathrm{wt} \%$ ). The first three of the four (FalC 120, 145, and 147) have a second sub-population that plots within a very consistent range, and may indicate a relationship between them. The three kimberlites are found in a cluster surrounding kimberlite 148 (Fig. 1), for which no geochemical data was available. This group has good diamond preservation potential based on the high magnesium contents (avg. $11.87 \mathrm{wt} \% \mathrm{MgO}$ ) and high $\mathrm{Cr}_{2} \mathrm{O}_{3}$ contents (avg. $2.35 \mathrm{wt} \%$ ).

The third grouping of ilmenites is defined by $\mathrm{Cr}_{2} \mathrm{O}_{3}$ contents that are independent of $\mathrm{MgO}$, resulting in a large degree of scatter (Fig. 2h). For example, Snowden 614 ilmenite compositions show that the main kimberlitic population (separate from the crustal population) has a wide range in $\mathrm{MgO}$ contents (8 to $16 \mathrm{wt} \%$ ) and $\mathrm{Cr}_{2} \mathrm{O}_{3}$ contents $(0.25$ to $4.6 \mathrm{wt} \%)$. These bodies have a good preservation potential as they have high average $\mathrm{MgO}$ content (11.95 wt \%) and moderate to high $\mathrm{Cr}_{2} \mathrm{O}_{3}$ (avg. $1.26 \mathrm{wt} \%)$.

In order to gauge the relative diamond preservation potential based on ilmenite compositions the $\mathrm{MgO}-\mathrm{Cr}_{2} \mathrm{O}_{3}$ plots were compared with those of Fipke et al. (1995), who distinguished categories of diamond preservation potential. Overall the DPP of central Saskatchewan kimberlites appears encouraging with many showing good to very good preservation potential 
(Table 1). Four kimberlites, FalC 116, 121, 326 and Snowden 603, apparently have a poor preservation rating based on their very low $\mathrm{MgO}$ and/or $\mathrm{Cr}_{2} \mathrm{O}_{3}$ contents.

\section{SUMMARY}

The compiled indicator mineral data are interpreted to suggest great variation in potential of individual Saskatchewan kimberlites to contain diamonds. The interpretations on diamond potential are based on relationships between indicator mineral geochemistry and diamond potential recognized by various workers including Gurney (1984), Gurney and Moore (1991), and Fipke et al. (1995) predominantly on South African kimberlites and Sobolev et al. (1973) on Russian kimberlites. The applicability of such relationships in assessing the potential of Saskatchewan kimberlites will only be known in time.

Some of the more prospective kimberlites have significant garnet composition populations plotting within the sub-calcic G10 field and include FalC 169, 120, 141, 121 and the Candle Lake kimberlites. In addition, strong calcium depletion in FalC 120, 141, 169 and Candle Lake 29 suggest stronger potential. Chromite compositions plotting in the diamond inclusion and intergrowth fields are well represented in FalC 120, 121, 141, and the Candle Lake kimberlites. Taken together, the garnet and chromite compositions indicate that the potential for peridotitic diamonds in many of the central Saskatchewan kimberlites is high. The potential for eclogitic diamonds remains unresolved as sodium contents of garnet have not been determined with sufficient accuracy, however many kimberlites have significant sub-chromian garnet populations (e.g. FalC 120 and 169) suggesting potential for such diamonds.

Overall, a few kimberlites appear to have potential to be significantly diamondiferous based on indicator mineral geochemistry. Caution must be exercised, however, as the data set may not be completely representative as one or even a few drill holes can be concentrated in zones that are atypical of a particular kimberlite. Additionally, many of the bodies are very large and may be comprised of several eruptive phases emplaced over millions of years. Thus one drill hole may only represent a small fraction of these complexly diverse bodies.

\section{REFERENCES}

Fipke, C. E., Gurney, J. J., and Moore, R. O., 1995. Diamond exploration techniques emphasizing indicator mineral geochemistry and Canadian examples. GSC Bulletin 423.

Gurney, J. J., 1984. A correlation between garnets and diamond in kimberlites. In: Glover, J.E. and Harris P.G. (Eds.), Kimberlite Occurrences and Origin: A Basis for Conceptual Models in Exploration. University of Western Australia Publication 8, pp. 143-166.
Gurney, J. J. and Moore, R. O., 1991. Geochemical correlations between kimberlitic indicator minerals and diamonds as applied to exploration. In Ross, J. (Ed.), Fifth International Kimberlite Conference. Brazil, Compania de Pequisa Rescursos Minerais, Special Publication 2/91, pp. 97-100.

Haggerty, S. E., 1975. The chemistry and genesis of opaque minerals in kimberlites. Phys. Chem. Earth, 9, 295-307.

Haggerty, S. E., 1986. Diamond genesis in a multiply constrained model. Nature, 320, 34-38.

Jellicoe, B. C., Robertshaw, P., Williamson, P., and Murphy, J., 1998. Summary of Exploration activities and results for the Fort à la Corne Diamond project, Saskatchewan. In Delaney, G. D., and Harper, C. T. (Eds.), Summary of Investigations 1998, Saskatchewan Geological Survey, Sask. Energy and Mines, Misc. Rep. 98-4, pp. 144-157.

Kjarsgaard, B. A., Leckie, D., McNeil, D., Heaman, L., McIntyre, D., 2001. Cretaceous kimberlite chaos? Fort à la Corne revisited, reworked, and resolved. In Delaney, G. D., Maxeiner, R. O., and Harper, C. T. (Eds.), Summary of Investigations 2001, Volume 2, Saskatchewan Geological Survey, Sask. Energy and Mines, Misc. Rep. 2001-4.2, pp. 64.

Kjarsgaard, B. A., Leckie, D., Bloch, J., McIntyre, D., McNeil, D., Stasiuk, L., and Haggart, J. W., 1995. Smeaton kimberlite drill core. GSC Open File Rept. 3170.

Leckie, D. A., Kjarsgaard, B. A., Bloch, J., McIntyre, D., McNeil, D., Stasiuk, L., and Heaman, L., 1997. Emplacement and reworking of Cretaceous, diamondbearing, crater facies kimberlite of central Saskatchewan, Canada. GSA Bulletin, 109, 1000-1020.

Lehnert-Thiel, K., Loewer, R., Orr, R., and Robert-Shaw, P., 1992. Diamond-bearing kimberlites in Saskatchewan, Canada: The Fort à la Corne Case History. Expl. Min. Geology, 1, 391-403.

Schulze, D. J, 1993. Garnet xenocryst populations in North American kimberlites. In Diamonds: Exploration, Sampling and Evaluation, Short Course Proceedings, Pros. Dev. Assoc. Can., Canada, pp. 359-377.

Scott-Smith, B. H., Orr, R. G., Robertshaw, P., and Avery, R. W., 1994. Geology of the Fort à la Corne kimberlites, Saskatchewan. Canadian Institute of Mining and Metallurgy Meeting, Oct., 1994, Proceedings, Canada, pp. 19-24.

Sobolev, N. V., Lavrent'yev, Yu, G, Pokhilenko, N. P., and Usova, L. V., 1973. Chrome-rich garnets from the kimberlites of Yakutia and their paragenesis. Contrib. Mineral. Petrol., 40, 39-52.

Contact: SE Harvey, Saskatchewan Industry and Resources, 2101 Scarth St, Regina, Sask, Canada, S4P 3V7, Email: sharvey@ir.gov.sk.ca 